\title{
UTOPIANS IN CLAYTON COUNTY, IOWA
}

\author{
by Gary W. Armstrong \\ Luther College \\ Decorah, lowa
}

Mr. Armstrong, a native of Marion, Iowa, is a twenty-one year old Junior and history major at Luther College in Decorah, Iowa.

\section{Acknowledgment:}

Much appreciation is expressed by the author to Richard G. Cole, an Associate Professor of History at Luther College, for suggesting the research topic of Communia and for supervising the research. Also, acknowledgment should be given to Professor Earl J. Leland of the Luther history department for reading the manuscript and making some valuable suggestions.

In the nineteenth century the American frontier was dotted with numerous small pleasant villages composed of simple homes, several stores, a frame church often doubling as a school and occasionally a modest industry. Surrounding these hamlets was a rich array of small farms, whose occupants had a hardy but simple life striving to extract a living from their land. This agrarian setting was the motif of opportunity in America.

In 1847 a small utopian colony, Communia, was founded in the north-eastern corner of Iowa. Although the colony never exceeded one-hundred persons, Communia proved the ruin of one of Europe's most outstanding communists of the preceding decade, drew the close attention of Carl Marx and degenerated into violent quarrels settled in both the streets and in court.

Europe's experience during the first half of the nineteenth century was markedly different from America's. In Europe the industrial revolution, although still in adolescence, was beginning to have a significant impact on social-economic patterns of life in isolated pockets of Europe. The psychology of every economic class and the life styles of the individuals within them were tragically shaken by industrialization; for most it meant seering humiliation, consuming frustration and endless 
despair. One group, the guild craftsmen, epitomized this experience as large-scale industry transformed these proud, prosperous artisans into tragic clowns bound to the past yet caught up in an industrial world programmed to reduce them to the level of the unskilled, city proletariat. As Joseph Wall in his definitive biography of Carnegie, Andrew Carnegie, vividly reveals in his treatment of William Carnegie, Andrew's father, many of these craftsmen never recovered from the crushing blow dealt them by industrialization. ${ }^{1}$ They were never able, after this event, to strive for the future but only long for the past. Other men responded to the chaos created by the industrialization in seeking a new order.

Francois Fourier, a posthoumous son of eighteenth century rationalism, writing in France during the early decades of the nineteenth century attempted to develop a new, saner industrial order through reason. ${ }^{2}$ His basic premise grew from the terrible anguish suffered by at least some men straining to adjust to a nascent industrialism. Fourier believed it was far easier to change the social environment to accommodate human nature than to adjust human nature to fit the social environment. Fourier reasoned that the social environment in closest harmony with man's nature was an extended family of sixteen hundred persons sharing all things in common in an aggrarian-handicraft setting. ${ }^{3}$ A substantial number of men, predominantly from France and Germany, who were hostile to the new developments of large-scale industry came to believe in the simple life style offered by Fourier. Soon groups of these Fourierists laid plans to establish experimental colonies. The years spanning 1832 through 1856 saw several score of the phalanxes set up throughout America.

In 1844, Andreas Dietch, a Swiss brushmaker, led a group of Swiss-Germans in establishing a Fourierish colony in Osage County, Missouri, which they called New Helvetia. ${ }^{4}$ Very little is known about this phalanx other than it failed within one year. The reasons for the quick demise are attributed to Dietch's death, lack of capital and bitter personal vendettas among the colonists. After the colony failed a number of its members moved to St. Louis to find employment. In St. Louis a number of these unsuccessful New Helvetian colonists fell under the spell of Heinrich Koch, a forceful communist journ- 
alist and orator, who was generally recognized as the leader of the German workers in the area. ${ }^{5}$ At the outbreak of the Mexican War he organized a company of soldiers, a number of which were from New Helvetia, in response to the United States Army's plea for volunteers. This company returning home in 1847, although they had seen no action, were handsomely remunerated for serving with land warrants. ${ }^{6}$ The federal government, like the New Helvetians and nearly everyone else in America, lacked liquid capital. To finance the Mexican war they issued land warrants good for sections of the public domain.

Ten men, some of whom had in their possessions land warrants, under the leadership of Heinrich Koch organized in St. Louis very early in 1847 for the purpose of establishing an experimental Fourieristic colony. The men associated with Koch were: Joe Venus, a black smith; Hanrich Babe, a carpenter; Jacob Bonsar, Cornelius Kopp and Issac Nagel, tailors; Johann Hofstaeder, a druggist; Isham Marxer, a shoemaker; Johan Enders, a locksmith; Joseph Kremper, a farmer; and Friedrich Meister, occupation unknown. ${ }^{7}$ Three of these men were formerly associated with New Helvetia: Joseph Venus, Johann Enders and Cornelius Kopp. These men chose a section of land in north-east Iowa as the site of their colony, located in the heart of Clayton County, about six miles south of Elkader and nearly fifteen miles west of Guttenberg. The colony was named Communia and the closest major city was Dubuque, over fifty miles to the south-east of the settlement.

Once the Mississippi was clear of ice in the spring of 1847 the small band of Fourierists traveled north to Dubuque by steamer. Apparently, those who had families left their loved ones in St. Louis. They remained in Dubuque for several days making preparations for the tough pioneering experience which lay ahead of them. After this brief layover they proceeded overland to the one-hundred and sixty acre plot they had purchased with their land warrants. These men, who sought to establish an agrarian-handicraft economy in Communia, must have been bitterly disappointed by the rockridden, steeply hilled country that greeted them. Aside from the excellent water, plentiful game and peerless, raw, natural beauty of the area, Communia was simply a terrible place to 


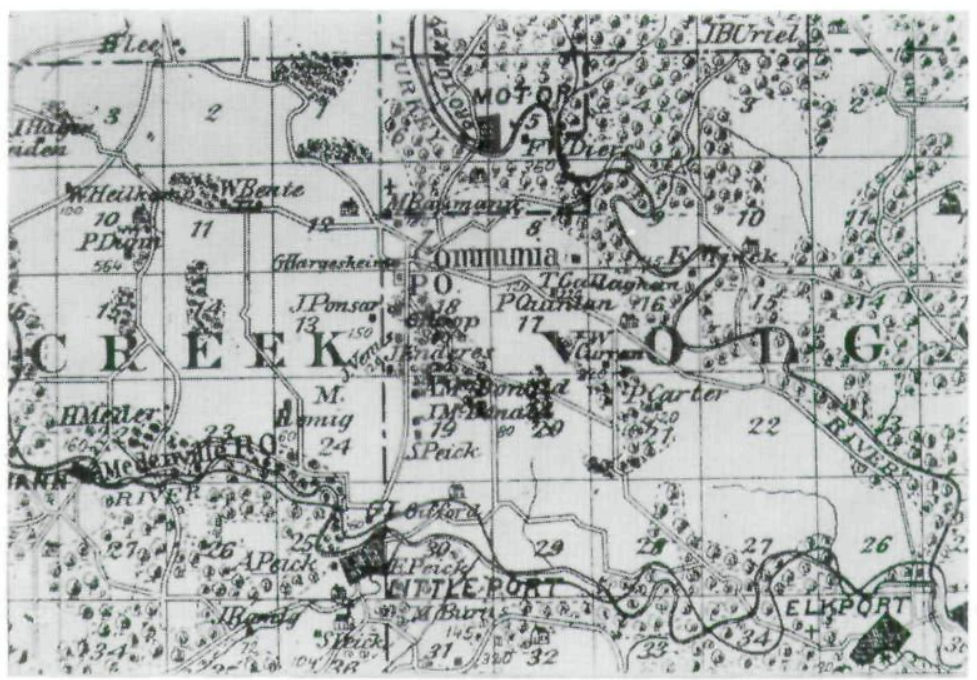

Map taken from A. T. Andreas' Illustrated Historical Atlas

of the State of Iowa-1875

\section{Map showing location of Communia}

farm. ${ }^{8}$ The natural handicaps of farming this area were compounded by the gross agricultural inexperience of these German craftsmen. The harshness of the land and the ineptness of the colonists never allowed Communia to establish a sound economic status throughout its history. Despite the agricultural disappointments, the colonists did make substantial progress during the first year. They built two crude log cabins, fourteen by twenty feet; a brick kiln, from which came the materials used in building a number of brick structures later on; a frame house, twenty by thirty feet and a blacksmith shop. ${ }^{9}$

Very little is known concerning the early years of Communia other than, like all frontier settlements, life was rough. One man, Frederich Meister, returned to St. Louis in less than two months. It is surprising that only one of these men withdrew from the experiment during the trying initial period since these urban craftsmen were largely unprepared for the hardships of the frontier.

Once the struggle with nature began to taper off-not because the men had won but rather because they had learned to live with nature-the men suspected that Henrich Koch, 
Communia's president, was embezzling their money. ${ }^{10}$ The situation grew more strained when it was discovered that Koch had registered all of Communia's land, which was now considerably more than the original one-hundred and sixty acres, in his own name. ${ }^{11}$ Under pressure, in the autumn of 1849, Koch left the colony after receiving six-hundred dollars for his share in the venture. The leadership of the colony passed to Joseph Venus, the blacksmith. Shortly after this incident the colonists drew up a document labeled The Articles of Association which transformed Communia into a legal person capable of holding land in its own name. The land was then transferred into the colony's name to prevent further squabbling over the issue of land ownership.

These Articles of Association outline the structure under which Communia operated. Fourieristic thought runs throughout the document as illustrated in the opening section when the purpose of the colony was given as "Agricultural, Mechanical Arts and Trades, and such other industrial pursuits and business as said association deem expedient and proper." Men wishing to join the association were given a three month trial period after which time if they were still willing to give all of their worldly possessions to the colony and received a favorable vote by two-thirds of the colonists they became a member. Once you became a member you automatically assumed an equal interest and rights in the colony, irregardless of original investment. These interests and rights as outlined in the Articles of Association consisted of sharing all the colony's resources in common and determining through the democratic process how these jointly held resources were to be employed. Each autumn the male members selected from amongst themselves a president, treasurer and secretary. The function of these officers was not to delineate Communia's future but to carry out the wishes of the entire colony. The colonists' desires were articulated at the meetings held every Saturday night to review the past week and plan for the immediate as well as extended future. In this manner the colonists shaped their environment to accommodate human nature. If the officers failed to perform adequately the duties assigned to them they could be impeached by a simple majority vote. Aside from an equal 
economic interest in the colony and the right to vote, the Articles of Association guaranteed the colonists a number of generous benefits in its social welfare section which is essential to Fourier's concept of the extended family. If a man became ill for an extended period or died, his family was to be provided for by the colony. Men and women unable to work due to the rigors of time were also maintained. If a member wished to leave the colony, he was given his original investment back with no interest in three installments covering a two year period. Members could also be forced to leave Communia for failure to observe rules of the colony and for immoral conduct by a two-thirds vote of the colonists. They were paid off in the same fashion as those who requested to leave.

In 1850, despite the harshness of the land, agricultural naivity of the colonists and three years of intermittant bitter, factional quarreling, Communia appeared to be prospering. The colony's male membership had increased from ten to thirteen despite the loss of five of the founders. Communia's original one hundred and sixty acres had grown to nearly one thousand acres valued at eighteen hundred dollars with improvements primarily as a result of the new member's investments. The colony's other assets, totaling twenty-two hundred dollars, included livestock, five hundred dollars; farm equipment, three hundred dollars; mechanical tools, two hundred dollars; and household goods, two hundred dollars. Communia's financial position was undeniably improved over the past, however, the colony was still plagued by a chronic lack of capital as the debts nearly matched its assets. ${ }^{12}$

The autumn of 1851 not only brought Communia a bountiful harvest but William Weitling, a leading figure in the Communist movement during the fourth and fifth decades of the nineteenth century. Born of humble German parents he was, out of economic necessity, apprenticed to a tailor as a young child. At the expense of a formal education the impressionable tailor's apprentice grew to understand the anxious psychology of the skilled workers facing industrialism. As a young man he balked at being conscripted into Prussian military service and was forced to leave the country. In 1835, after traveling throughout Europe as a journeyman tailor, he settled in Paris. Weitling, who had already shown signs of radicalism, when 
exposed to the revolutionary ideas of Francois Babeuf, Saint Simon, Francois Fourier, Father Cabet and myriad others which saturated the workingmen's quarters of this intellectual mecca, committed himself to radical social change. Soon he took to the road, as an evangelical communist, preaching his own brand of Communism. Weitling's Communism was a very simple doctrine steeped in primitive Christianity as its basic tenets were human brotherhood and self-sacrifice. ${ }^{13}$ His Communism, as outlined in his major work, Guarantees of Harmony and Freedom, published in 1842, struck a responsive chord among the working class. He was recognized as the most influential figure among the sizeable German workingmen's colonies in Switzerland, Belgium, France and England. Praise for his work came not only from the workers but from intellectuals such as Karl Marx who hailed Weitling's contribution as: "The tremendous and brilliant debut of the German Working Class." ${ }^{\prime 4}$ As the years passed Marx came to view Weitling in a different light as he became somewhat sensitive of the great popularity enjoyed by the tailor and more importantly foresaw that Weitling's sentimental communism had no place in the scientific doctrine he was striving to formulate. In 1846 these two publicly split over ideology in a violent debate which ended when Marx raged, "Ignorance has never helped anyone yet!"15 With Marx's formidable forces unleashed to undermine Weitlings position in the communist movement, his influence began to wane. Discouraged, he left Europe, except for a short return during the German Revolution of 1848 , for America. Soon after landing in New York City, Weitling began working for social reconstruction in the United States. To achieve a social revolution Weitling offered a three-headed program consisting of: the establishment of a working men's league dedicated to exercising a powerful influence on questions of wages and working hours and uniting all existing worker's insurance and benevolent activities under a central treasury strong enough to pay sick benefits and old age pensions to its members; a newspaper functioning as a mouthpiece for the league; and a colony serving as the headquarters, resthome and showcase of the league. ${ }^{16}$ Weitling swiftly set his program in motion for by the time he first set foot in Communia he had established a workingmen's League with 
twenty chapters scattered throughout the country with a combined membership numbering approximately three thousand consisting primarily of skilled German workers, founded a weekly publication, The Worker's Republic, printed in German with a circulation of nearly four thousand, ${ }^{17}$ and observed numerous colonies in preparation for setting up his own.

Weitling came to Communia in the autumn of 1851 while traveling through the mid-west on League business to visit several of the colonists he had known intimately in Europe years ago. The stunning aesthetic beauty of the area, particularly in the fall, and the earnest initiative shown by the colonists moved Weitling on his first of many visits to Communia to write, "For the first time I am standing on the holy soil of a fraternal community whose inhabitants have undertaken to live, not half and one-sidedly, but wholly for the sacred cause of Communism." So favorably impressed was he that he envisioned Communia linking with the League in accordance with the third phase of his program of social reconstruction. The colonists when propositioned by Weitling readily agreed to pledge all of Communia's assets to the League for whatever capital it promised to invest in the colony, primarily in response to the critical lack of capital which had shackled their development for so long. Before the year was over the League had plugged nearly four hundred dollars into Communia. $^{18}$

Over the years the general quality of life had improved manifold in Communia. The original crude log cabins had been gradually replaced by wooden frame or brick structures. One two-story frame building, sixty feet by thirty-five feet, served as the living quarters for the colonists. This structure contained five apartments to accommodate families and a large barracks for unmarried colonists. Meals were prepared in a common kitchen by the women and served in a common dining hall at 6:30 A.M., noon, and 6:30 P.M. and, in between, milk, cheese, coffee and whiskey were available. ${ }^{19}$ The meals were simple and wholesome. Aside from the meals, the women were responsible for the colony's poultry, washing and gardening. The women continually grumbled over having to do work for people outside their family. During the growing season most 
of the men busied themselves in agriculture pursuits. On the one hundred cultivated acres of Communia's large tract the colonists grew wheat, oats, potatoes, barley, and assorted fruits. ${ }^{20}$ Wheat was by far the most important crop even though residents of Clayton County good-naturedly referred to Communia as "Potato Prarie." ${ }^{21}$ Their land also supported livestock which at the time of Weitling's first visit consisted of onehundred pigs, thirty oxen, fifteen sheep, seven horses and innumerable poultry. ${ }^{22}$ Following the fall harvest the craftsmen worked at their respective trades for the benefit of the colony. Life was not the struggle it had been but it was still tough in 1851. Hard as life was the colonists still found time to enjoy themselves. On Saturday night, following the weekly organizational meeting, the colonists forgot the troubles of the week by singing and dancing while sipping on beer which they brewed themselves. ${ }^{23}$

Communia in 1852 could best be characterized as quarrelsome. The petty bickering concerning the women's workload and the colony's administration, which had always troubled Communia, was amplified when Weitling, returning in July of 1852, asked Krisinger, the president of Communia, to sign a deed of trust in the amount of five thousand dollars for one year at ten percent interest to safeguard the League's sizable investment. Krisinger refused arguing that a simple promissory note would serve as adequate protection. Weitling, however, insisted on a deed of trust and applied economic pressure to the colony to hold a special election of officers. In the ensuing election Joe Venus, who favored signing the deed of trust, triumphed over Krisinger, who immediately left the colony taking three other men and their temperamental wives. One of these men, Louis Weinel, successfully sued Communia two years later for two hundred dollars for failure to pay off a promissory note of one hundred and twenty dollars and a land warrant for forty acres. ${ }^{24}$ The colony's failure to pay Weinel promptly is puzzling in that by the end of 1852 the League and individuals of the organization had generously invested eight thousand dollars in Communia. During this same year League members, attracted by the glowing descriptions of the colony offered in The Worker's Republic, first arrived. Within a matter of months two factions emerged-one com- 
posed of the "old" colonists the other of "new" colonists who's primary loyalty lay with the League and Weitling rather than the colony. The situation worsened in December when it was discovered that Weitling had purchased a forty acre plot banking the Volga River and repeated Koch's mistake of registering it in his own name. This remained a sore point throughout the remainder of the colony's history. These disputes were all symtoms of a cancerous resentfulness infesting the "old" members as the League and Weitling became more and more influential in the colony they had toiled and sacrificed to build.

Weitling perceived the colony's financial and internal problems as stemming from poor organization and demanded the Articles of Association be replaced by a new constitution. In July of 1853 with cautious permission the colonists, who had by this time become economic pawns of Weitling's League, endorsed the new constitution Weitling had drawn up. The major accomplishment of the constitution was to weld the Workingmen's League and the colony. The document changed the colony's name from Communia Colony to Communia Workingmen's League.

The new organizational structure delineated by this lengthy document was much more detailed and complicated than the Articles. of Association. The guidelines for admission to the colony were unaltered. While everyone still maintained an equal economic interest, irregardless of original investment, they no longer enjoyed political equality. Only those members who lent the colony one-hundred dollars for every adult member of their family and fifty dollars for every child, for a period of ten years with no interest, were allowed to vote. Each year these men elected from amongst themselves a board of trustees not to exceed twenty-five members. The trustees would then elect from amongst themselves an administrator, secretary and treasurer. This electoral procedure left the "old" members, who had established large families and invested the bulk of their capital previously in the colony, politically anemic. The people unable to meet the stringent financial demands were given their only political voice in the selection of foremen for the three working divisions set up by the new constitu- 
tion-building, farming and crafts. Each week these foremen along with the administrator, treasurer and secretary, after reviewing written proposals submitted by the workers, drew up contracts specifying the hourly wages or salaries in harmony with the object of the association-to be paid on completion of given tasks. Pay for work or produce was in colony scrip. This scrip was used in paying room and board as well as in purchasing goods at the colony store priced at ten percent above costs "for the pension fund and another ten percent for costs of administration and sustaining the sick." Aside from this, each worker was required to "pay monthly into the sick fund the earnings of at least one day's labor." For the first time the new constitution allowed the colonists to establish their own households provided they bore the expenses, and to farm their own section if they agreed to pay rent set at ten percent of the land's value. The procedures for expulsion and for voluntarily leaving the colony remained unchanged. All the innovations introduced by the new charter fouled the pure communism the colony had operated under previously by creating economic classes and opening the door

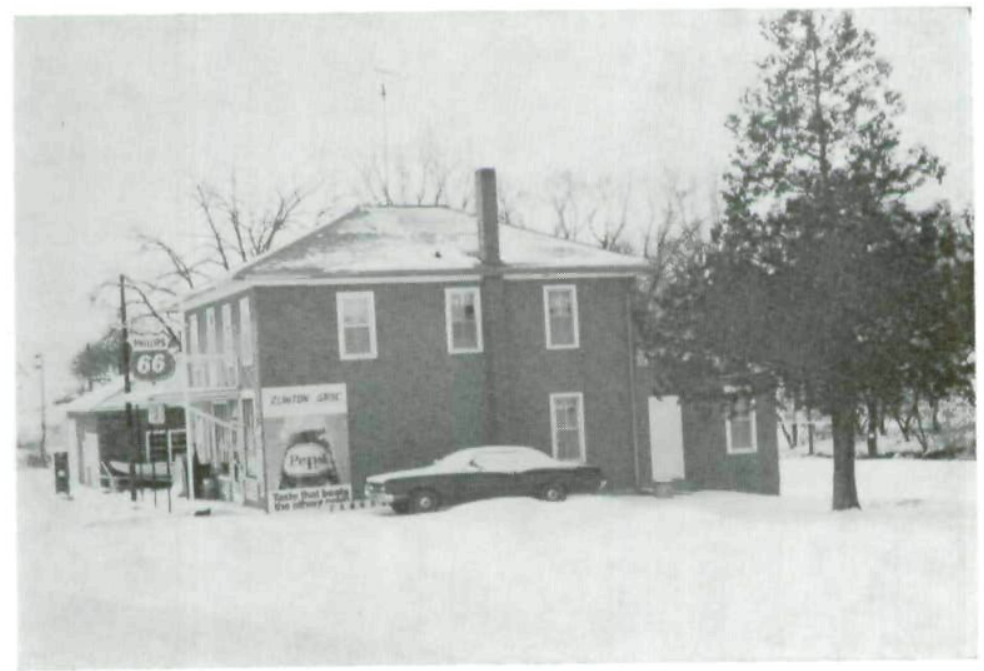

Courtesy of Autbor

This grocery was Communia's colony store and is still in use today. 
to capitalism cloaked in private initiative. Twenty-one men signed this document of which only eight qualified for trusteeship. Significantly, none of these trustees were among the four remaining founders of the colony nor do their names appear on the Articles of Association's roster. ${ }^{25}$

The financial situation of the colony was complicated in July of 1853. Communia's assets totaled eleven-thousand dollars with fourteen-hundred and forty acres, six-thousand dollars; livestock, two-thousand five hundred dollars; mechanical tools and farming equipment, one thousand fifty dollars; provisions and store goods, nine hundred twenty dollars; and material for building, six hundred and thirty dollars. ${ }^{26}$ While this eleven thousand dollar figure is impressive as it more than triples the total assets listed in the Articles of Association and represents a favorable balance of three thousand dollars, it was disappointing for the League and individuals associated with it who had invested nearly fifteen thousand dollars in the colony since $1851,{ }^{27}$

In November of 1853 the first regularly scheduled election was held under the new charter with Weitling, who had returned to New York on League business, appointed administrator. Hesitatingly, he accepted the position which substantially added to his already formidable influence over the colony. Karl Marx, who somewhat surprisingly kept close watch over Weitling's activities, grasped the vast potential power he wielded over Communia when he referred to Weitling as "the dictator of the colony, Communia."28 Despite his position of power Weitling was unable to best the centrifugal forces which were tearing Communia apart at the seams. Arriving in Communia, he found to his great dismay that the colonists were taking advantage of the new charter by setting exorbitantly high wages for themselves while establishing ridiculously low rates for services they received from the colony which resulted in the colony's favorable balance of three thousand dollars in July dwindling to five hundred and sixty dollars by the end of the year. ${ }^{29}$ In attempting to re-establish economic order Weitling met determined resistance from both "old" and "new" colonists unwilling to give up their good thing and were all the while harassing their administrator 
concerning the land he had registered in his own name. Weitling also pressed for the immediate completion of a project, in the making for over a year, to dam the Volga River in order to develop sufficient water power to power a flour mill. The scheme had been and continued to be sabotaged by human as well as nature's caprice. Although over six thousand dollars was spent on this project the dam and flour mill were never finished. ${ }^{30}$ The soft murmurs of doubt concerning the League's large investments in Communia, which had been heard in the organization's meeting halls for sometime, rose to howls of rage as reports on conditions in the colony appeared in The Worker's Republic. Weitling, hounded on all sides, left the colony in January of 1854 , apparently to escape the badgering of the colonists and quell the growing rebellion in the League.

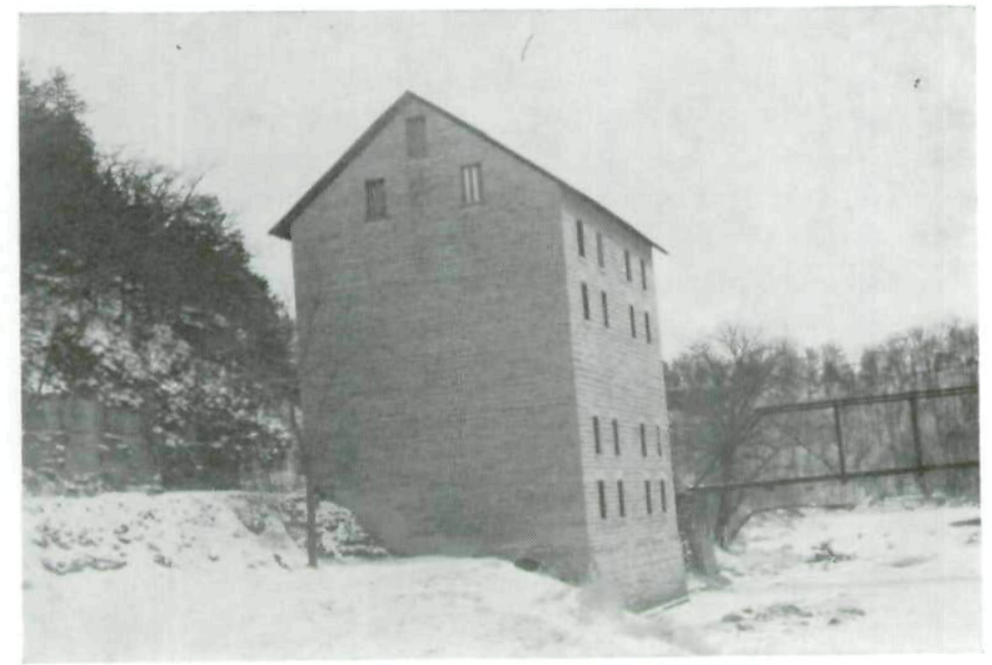

Courtesy of Author

Motor Mill, looking towards the East. It is located in settlement called "Motor" in Map photograph on page 926.

Despite the quarrelsome nature of the colonists and unlike many foreign language utopian settlements, Communia enjoyed a healthy relationship with the Yankee frontiersmen. This editorial comment in one of the county's leading news- 
papers is exemplary of the cordial relationship: "Communia is an association of Germans after the style of Fourierism. We hope the political results may fully meet the theory of the association." ${ }^{31}$ Communia occasionally responded to friendly gestures like these by hosting well attended parties where the beer flowed freely. The natives' willingness to accept Communia can best be explained by the large percentage of Germans in this area as the names of the immediate towns would suggest: Elkader, Guttenberg.

Following Weitling's abrupt departure the colonists rallied and carried on as before. Unfortunately the League which served as the colony's economic lifeline was both unwilling and unable to financially assist Communia. Without financial assistance the colony was destined for economic collapse. Soon a majority of the colonists began to press for the liquidation of Communia. Early in June of 1854 the colony was put up for sale. Apparently no one was interested in purchasing it so the colony was forced to limp through another year. As time passed relations between the colonists worsened. Epitomizing this developing condition in April of 1885 a group of "new" colonists attacked "with knives, sticks and pistols" a group of "old" colonists. ${ }^{32}$ The situation then deteriorated into an exceedingly complicated court battle. The June court docket alone listed eight cases involving Communia. ${ }^{33}$ The all important question of who was to get what raged in the courts through 1864 . What finally did happen is now undeterminable as a large share of the courts' decisions concerning Communia have been lost. ${ }^{34}$

Most of the colonists had left the colony by 1856, a large percentage of them remaining in Clayton county. At this time the Workingmen's League had dissolved, largely as a result of its association with Communia, and Weitling was working as an immigrant official in New York City. In attempting to capture the dynamics of Communia's failure one could point to a myriad of contributing factors, the primary ones being: an acute lack of capital, poor farmers farming poor land, a lack of dedication to communist principals particularly among "new" colonists, and the new charter opening the door to capitalism. Underlying all these things and others, however, is a concept basic to the demise of Communia as well as all the other ex- 
perimental utopias in America at this time. The vigor of American capitalism with its abundant economic opportunity made the communal societies designed to break through the cartel structure of Europe both impractical and uncomfortable. Today with the recent rash of communes or experimental societies one wonders if American Capitalism still retains the vigor to best this challenge.

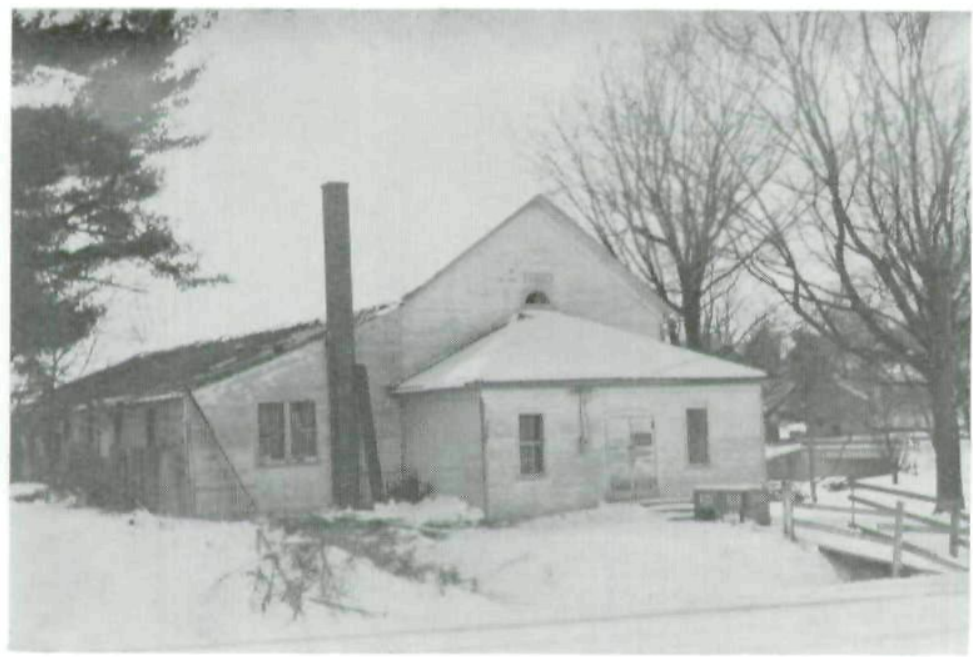

Courtesy of Autbor

Front view of Turnverein. This building was constructed by a number of colonists after the dissolution of Communia. It was built to serve as a meeting hall and gymnasium, hence the name "Turnverein" as it is referred to by local residents. The building is in the process of being destroyed, and sections of it are considerably older than the 1883 date listed on the front.

\section{NOTES}

${ }^{1}$ Joseph Wall, Andrew Carnegie. (New York: Oxford University Press, 1970).

${ }^{2}$ Encyclopedia of the Social Sciences, 1st ed. (1931), S. U. "Fourier and Fourierism" by Edward Mason.

${ }^{3} I$ bid. Also see for an overview of Fourier's work: Charles Fourier, The Social Destiny of Man. (New York: Robert M. Dewitt, 1857.)

${ }^{4}$ Carl Wittke, The Utopian Communist. (Baton Rouge: Louisiana State University Press, 1950) p. 239. This is the definitive work on Wilhelm Wittke written in English. 
${ }^{5}$ Ibid. p. 240.

${ }^{6}$ George Schultz-Bebreud, "Communia, Iowa, a Nineteenth century German American Utopia" Iowa Journal of History 48 (January 1950): 27-54.

${ }^{7}$ Wittke, Utopian Communist, p. 242.

${ }^{8}$ Today the roads of the area are banded with many fallow fields and abandoned farm houses.

${ }^{9}$ History of Clayton County (Chicago: Inter-State Publishing Co., 1882 ), p. 1117.

${ }^{10}$ Wittke, Utopian Communist, p. 242.

${ }^{11}$ Clayton County Deed Records (Elkader, Iowa).

${ }^{12}$ Clayton County (Elkader, Iowa) Communia Colony's Articles of Association, Book F. p. 137-139.

${ }^{13}$ G. D. Cole, A History of Socialism Thought, Vol. I. The Forerunners (London: Mac Millan, 1959), p. 228. 1968).

${ }^{14}$ Harry W. Laidler, History of Socialism (New York: Cromwell,

${ }^{15}$ Edmund Wilson, To the Finland Station (New York: Doubleday, $1940)$, p. 165.

${ }^{16}$ Wittke, Utopian Communist, p. 138-9.

${ }^{17}$ Ibid. p. 146.

${ }^{18}$ Ibid., p. 243.

${ }^{19}$ Ibid., p. 247. 1854.

${ }^{20}$ Clayton County Archives, Communia Inventory, Vertical File,

${ }^{21}$ Ruth S. Beitz, "Communia" The Iowan 15 (Fall, 1969), p. 41.

${ }^{22}$ Wittke, Utopian Communist, p. 244.

${ }^{23}$ Ibid., p. 262.

${ }^{24}$ Clayton County Archives, Vertical File, 1854. Weinel vs. Communia Workingmen's League.

${ }^{25}$ Clayton County (Elkader, Iowa) Constitution of the Association called Communia Workingmen's League, Book I, p. 39-46. Also The Herald, 5 August 1853.

${ }^{26}$ Ibid.

${ }^{27}$ Wittke, Utopian Communist.

${ }^{28}$ Ibid., p. 119.

${ }^{29}$ Ibid., p. 253.

${ }^{30}$ In 1864 John Thompson successfully dammed the Volga and erected a large seven story flour mill at a cost of fifty thousand dollars! ${ }^{31}$ The Herald, 5 August 1853.

${ }^{32}$ Clayton County, Vertical file, 1855. Joseph Venus vs. Michael Bouman.

${ }^{33}$ The Herald, June 23, 1854.

${ }^{34}$ The Herald, 1 June 1855. 
Copyright of Annals of Iowa is the property of State of Iowa, by \& through the State Historical Society of Iowa and its content may not be copied or emailed to multiple sites or posted to a listserv without the copyright holder's express written permission. However, users may print, download, or email articles for individual use. 